\title{
TRANSFER OF PROPERTY BASED ON PROPERTY LAW RULES AND CONTRACT LAW RULES UNDER FORTHCOMING KOSOVO DRAFT-CIVIL CODE
}

\author{
Prof. dr. sc. Haxhi Gashi* \\ Dr. sc. Bashkim Preteni**
}

\author{
UDK 347.23(497.115) \\ https://doi.org/10.30925/zpfsr.42.1.8 \\ Ur.: 19. prosinca 2020 \\ Pr.: 13. veljače 2021. \\ Pregledni rad
}

\begin{abstract}
Summary
In most civil law jurisdictions, the contract is the most used derivative title for the transfer of ownership (movable and immovable property). Very often, the law of property and law of contract are seen as distinct and one can envisage their role from different legal perspectives. This is closely connected with the type of transfer system based on whether the (Austrian) causal system, (German) abstract system or (French) consensual system is applicable. Kosovo is in the process of civil law codification and the Kosovo Draft-Civil Code which has followed the application of the causal system of transfer of property and such an above mentioned interaction of these two branches of civil law is mandatory, and only with a common survey can the contractual transfer of property be illustrated. The aim of this paper is to focus solely on the influence of contract law rules in connection with the acquisition of ownership over movable and immovable property determined by Kosovo Draft-Civil Code.
\end{abstract}

Keywords: Kosovo law; Civil code; Law of property; Law of contract; ownership; contract.

\section{INTRODUCTION}

As a starting point, it has to be made clear that Kosovo does not have a Civil Code. ${ }^{1}$ Under Kosovo law, the civil law relationships are regulated by special laws such as: (i) Law on Property and Other Real Rights (LPORR); (ii) Law on Obligations (LOR); (iii) Law on Family (LOF) and (iv) Law on Inheritance (LOI). ${ }^{2}$ These laws

* Haxhi Gashi, Ph.D., Associate Professor, Faculty of Law University of Prishtina "Hasan Prishtina"; haxhi.gashi@uni-pr.edu. ORCID: https: https://orcid.org/0000-0002-2752-5646.

** Bashkim Preteni, Ph.D., Teaching Assistant, Faculty of Law University of Prishtina "Hasan Prishtina"; bashkim.preteni@uni-pr.edu. ORCID: https://orcid.org/0000-0002-2297-5584.

1 Regional countries as Macedonia, Serbia, Bosnia, Montenegro, Slovenia and Croatia do not have a civil code also.

2 Law No 03/L-154 on Property and Other Real Rights published in Official Gazette № 57 of 4 August 2009; Law No 04/L-077 on Obligational Relationships published in Official Gazette 
are quite new in Kosovo's legal framework and are mainly the result of international organisations and experts who helped authorities to establish the legislation after the war in Kosovo in 1999. Generally, the legislation was drafted based on two notions. Firstly, the most modern countries were taken as an example, i.e., the LPORR was drafted in the spirit of the German Civil Code. ${ }^{3}$ Secondly, some legislation remained the same despite the fact there were adopted new laws but which did not make any significant modernisation or change. For such an example can serve the current LOR which provides no difference to the LOR of ex-Yugoslavia, apart from exclusion of the provisions related to the social property, contracts related to the socially owned organisations and related issues. ${ }^{4}$ Current LOR is based also in the Slovenian Code of Obligations which is also based on LOR of ex-Yugoslavia. ${ }^{5}$

The regulation of the rules of civil law in such a form has created divergences and a lack of legal certainty. Consequently, the idea to bring together all these laws in one single document called civil code was introduced. Thus, Kosovo has started the process of civil law codification and the consolidated draft has been approved by the Government of Kosovo and currently it is in the procedure within the Assembly of Kosovo. ${ }^{6}$ It seems that the year of 2021 will be crucial for the decision of having the Kosovo Civil Law in place. ${ }^{7}$ The Kosovo Draft-Civil Code (hereafter: KDCC) has 1630 articles and is divided into 5 books (in Albanian: libra) as follows:

- Book 1: General Part;

- Book 2 on Obligations;

- Book 3 on Property and Other Real Rights;

- Book 4 on Family; and

- Book 5 on Inheritance. ${ }^{8}$

By this division, the German pandectian Civil Code is followed contrary to Austrian and French systems. ${ }^{9}$ Nevertheless, as for the content of the KDCC, we

№ 16 of 19 June 2012; Law № 2004/32 on Family published in Official Gazette № 4 of 1 September 2006; Law No 2004/26 on Inheritance published in Official Gazette № 2005/7.

3 For instance, with regard to the acquisition and loss of ownership see Haxhi Gashi, "Acquisition and Loss of Ownership under the Law on Property and Other Real Rights (LPORR): The influence of the BGB in Kosovo Law", Hans Law Review 9, № 1 (2013): 41-60.

4 See and compare the current LOR with Law on Obligational Relationships published in Official Gazette of forms Yugoslavia No 29/78 and amendments of 1985 and 1989 published in Official Gazette $N^{\circ} 39 / 85$ and 5/89. It is worth to mention that the current LOR is almost identic also with The Slovenian Obligation Code published in Official Gazette of the Republic of Slovenia № $83 / 2001$.

5 See and compare current LOR with The Slovenian Obligation Code published in Official Gazette of the Republic of Slovenia No 83/2001.

6 The Kosovo Draft Civil Code is available in Albanian, Serbian and English in this link: http:// konsultimet.rks-gov.net/viewConsult.php?ConsultationID $=40578$.

7 The promulgation of this project by the Kosovo Assembly is a process which is depended by politics. Thus, this aspect is not subject of this paper. Nevertheless, as a legal text it has started to be treated by legal doctrine.

8 For more see Haxhi Gashi, "Pjesa e Përgjithshme e të Drejtës Civile - Parimet e Përgjithshme", in: Hyrje në Sistemin Ligjor së Kosovës, eds. Arsim Bajrami et al. (Prishtinë: Akademia e Drejtësisë së Kosovës, 2019), 168 et seq.

9 For the structure of these most important civil law countries see Konrad Zweigert and Hein 
cannot conclude that the German Civil Code has been fully followed. ${ }^{10}$ By contrast, the contractual model of the transfer of property under KDCC is similar to Austrian law. Such a solution followed by KDCC is more than welcomed and keeps the current tradition which has been considered as a successful one. Consequently, this means that the transfer of ownership is based on the contract and delivery in case of movable property or registration of ownership in the register in case of immovable property. In addition, the KDCC has mainly kept the current legal framework - but different modernisations are made for each book and in particular Book 1 on General Part is completely new, fulfilling the gaps of the current civil law system which lacked such rules.

With regard to the aim of this article, the legal interaction of Book 2 on Obligations and Book 3 in Property and Other Real Rights is evident and the contractual transfer system cannot be presented without a deep legal connection. Book 3 on Property and Other Real Rights determines the requirements for the acquisition of ownership in movable and immovable property: Right on ownership may be acquired by a legal transaction, inheritance, court decision, decision of another administrative body, and based on a law. ${ }^{11}$ The term legal transaction (in Albanian: punë juridike) refers to the contract which is regulated by Book 2 on Obligations and the testament which is regulated by Book 5 on Inheritance. ${ }^{12}$ This comes from Book 1 on General Part which defines the notion of the legal transactions as the following: A legal transaction is a legal declaration of the will of a natural or legal person in order to create, change or terminate civil rights or obligations..$^{13}$ Further, Book 3 on Property and Other Real Rights determines that: Ownership passes from the former owner to the acquirer by a valid legal transaction, according to the method laid down by law. ${ }^{14}$ Indeed, by this rule, we have to understand that a valid transaction is always required, while other formalities are determined based on the type of property that is transferred. Below, only the influence of contract for the acquisition of ownership in movable and immovable property is elaborated and other nearly topics remain for other scientific articles.

Kötz, translated from the German by Tony Weir, Introduction to Comparative Law, Second Edition (New York: Oxford University Press 1987), 76-186; Reinhard Zimmermann, "The Civil Law in European Codes", in: Regional Private Laws and Codification in Europe, eds. Hector L. MacQueen, Antoni Vaquer, Santiago Espiau Espia, (New York: Cambridge University Press, 2003), 18 et seq.

10 The abbreviations of the civil codes in this paper are as in the following: German Civil Code (BGB); Austrian Civil Code (ABGB); Italian Civil Code (ICC); French Civil Code (FCC).

11 KDCC, Article 863.

12 KDCC (book 2) Article 91 defines the contract as: The contract is an agreement between two or more parties which is intended to create, amend or terminate a binding legal relationship between them, or have any other legal effect. While, KDCC (book 5) Article 1535 defines the testament as: A will implies the expression of final willpower foreseen by law, by which the decedent orders the distribution of his property after his death.

13 KDCC, Article 54 (1).

14 KDCC, Article 864 (1). 


\section{RIGHTS IN REM AND PERSONAL RIGHTS KDCC}

The distinction between the law of property and the law of obligations is in line with the distinction between absolute rights (rights in rem) and relative rights (personal rights) and is fully adopted under the KDCC. Nevertheless, by way of regulation, it should be noted that under the KDCC there is no provision provided which, with a unitary approach, gives the meaning and the differences of the rights in rem and personal rights. In this context and from a comparative point of view, it is worth mentioning Austrian law which has very clearly made such a distinction. ${ }^{15}$ The KDCC Book 2 on Obligations regulates the personal rights or the relationships from the law of obligations, while the rights in rem or rights from the law of property are a subject of the KDCC Book 3 on Property and Other Real Rights. By the technique of the drafting and legislative perspective, the mentioned Austrian model of distinguishing the rights in rem and personal rights in one provision as in Article 307 of the ABGB would be very useful and it could be regulated as a general principle within the Book 1 on General Part of the KDCC.

\section{REQUIREMENTS FOR THE ACQUISITION OF OWNERSHIP}

The concept of ownership is the central institute of Book 3 and is defined as: Ownership is the comprehensive right over an asset. The owner of a property may, deal with the property as he wills, in particular possess and use it, to dispose it off and exclude others from any interference, as long as this is not in contrary to the law or with the rights of the other person. ${ }^{16}$

The definition provided by the LPORR is made using approximately the same approach as the majority of codified countries. ${ }^{17}$ So far, the French Civil Code determines that ownership is the right to enjoy and dispose of things in the most absolute manner, provided that they are not used in a way that is prohibited by statutes or regulations. ${ }^{18}$ On the other hand, the German BGB determines that the owner of a thing may deal with the thing at his discretion and exclude others from every influence - as long as it does not conflict with a statute or third-party rights. ${ }^{19}$ The Italian Civil Code establishes that the owner has the right to enjoy and dispose of the things fully and exclusively, within the limits and with observance of the obligations established by the legal order. ${ }^{20}$ Finally, the Austrian law gives the notion of ownership from an objective and subjective viewpoint, by stating that ownership is the right to freely

15 See ABGB, Article 307 determines as the following: Rights, to which a person is entitled without considering specific persons, are called rights in rem. Rights which exist only against a specific person with respect to an asset and arise directly pursuant to law or a legally binding action are called personal rights.

16 KDCC, Article 840. Further, the LPORR, Article 18 determines the same definition.

17 See Bram Akkermans, The Principle of Numerus Clausus in European Property Law (Antwerp - Oxford - Portland: Intersentia, 2008), 89-98, 175-180 and 256-262.

18 See FCC, Article 544.

19 See BGB, Article 903.

20 See ICC, Article 832. 
enjoy the substance and the benefits of an asset and to exclude everyone else therefrom (subjective meaning). ${ }^{21}$

From a comparative point of view, the main contractual transfer systems are as follows: the ( $i$ ) causal system; (ii) abstract system; and (iii) consensual system. ${ }^{22}$ Generally, the Austrian causal system requires a valid contract and the delivery of the movable property or registration in the land register of the immovable property. ${ }^{23}$ The German abstract system is the most characteristic system, requiring a contract from the law of obligations, the act for the transfer from the law of property and the delivery of the movable property or registration in the land register of the immovable property. Under the German system the contract from the law of obligations is not crucial for the acquisition of ownership - it creates only obligations between parties. However, the act of transfer (real agreement) makes the transfer possible. ${ }^{24}$ This is otherwise known as ( $i$ ) Trennungs; and (ii) Abstraktionsprinzip (principles of separation and abstraction) and is the main feature of German property law. ${ }^{25}$ The French consensual system depends solely on the contract. Under this system, the movable and immovable transfer is made according to a valid contract. ${ }^{26}$ Even for immovables, the registration is not made for the acquisition of ownership but for the protection of third parties. In other words, the registration has a declarative effect.

As with other civil law countries, the KDCC also has different rules for the acquisition of ownership in movable and immovable property. The main differences lie in the following characteristics: (i) Form of the contract; (ii) Requirement of an intermediator (notary) during the conclusion of the contract; (iii) Delivery of the property; (iv) Registration of the contract in the land register. ${ }^{27}$ Thus, these three

21 See ABGB, Article 353 and 354.

22 See generally Lars Van Vliet, Transfer of Movables in German, French, English and Dutch law (Nijmegen: Ars Aequi Libri, 2000), 201-205; Lars Van Vliet, “Transfer of Property Inter Vivos", in: Comparative Property Law - Global Perspectives, eds. Michele Graziadei and Lionel Smith (UK and USA: Edward Elgar, 2017), 150-168; Christian Von Bar and Ulrich Drobnig, The Interaction of Contract Law and Tort and Property Law in Europe - A Comparative Study (Munich: Sellier. European Law Publishers, 2004), 324-328.

23 For the transfer of movables under Austrian system see Wolfang Faber, "National Report on the Transfer of Movables in Austria", in: National Report on the Transfer of Movables in Europe, eds. Wolfang Faber and Brigita Lurger. Munich: Sellier. European Law Publishers, 2008), 58 et seq.

24 For the transfer of movables under German system see Mary Rose McGuire, "National Report on the Transfer of Movables in Germany" in: National Reports on the Transfer of Movables in Europe, eds. Wolfgang Faber and Brigitta Lurger (Munich: Sellier, European Law Publishers, 2011), 71 et seq.

25 Jens Thomas Füller, "The German Property Law and its Principles", in: Rules for the Transfer of Movables - A Candidate for European Harmonisation or National Reforms?, eds. Wolfgang Faber and Brigitta Lurger (Munich: Sellier, European Law Publishers, 2008), 199 et seq.

26 For the French transfer system see Eleanor Cashin Rataine, "National Report on the Transfer of Movables in France", in: National Reports on the Transfer of Movables in Europe, eds. Wolfang Faber and Brigitta Lurger, (Munich: Sellier, European Law Publishers, 2011), 75 et seq.

27 As it will be illustrated in the following treatments (III, 2 and 3) the transfer of immovables requires more formalities than the transfer of movables. Indeed, this is a rule that find application 
requirements find application in the transfer of immovable property contrary to the transfer of movables that is exceptionally required any of these conditions. Generally, if we compare the Kosovan model with the German, Austrian and French system, there is no doubt that KDCC has fully followed the Austrian causal system for the transfer of property despite the fact that there are also some similarities in place with the German system. From the legal eyes of the authors, such a solution provided by KDCC is proper and reflects the legal tradition of the legal system. Furthermore, the solution offered by the KDCC that the registration of contract has a constitutive effect for the acquisition of ownership in immovables has reconfirmed the legal certainty as a consequence that the notary system is new and are present the different practical deformations. ${ }^{28}$ In this context, the possible recognition of the French declarative effect of registration would have a negative impact in the legal system and the notaries and cadastral system would be seriously challenged and affected. It would reflect even in the legal transactions of citizens and legal entities. Finally, the German abstract system requiring two acts for the acquisition of ownership in immovables would create additional expenses for the contractual parties and would not bring any innovative solution that is in function of the Kosovo legal system.

\section{Movable and immovable property under the KDCC}

The distinction of things as movable and immovable was not discovered in this century. By contrast, this division has been recognised since the definition of things in Roman law. The most effective reason for this division is based on the rules of the acquisition of ownership. ${ }^{29}$ The KDCC has given the definition of the concept of things (in Albanian: sendet) as the following: Things are considered corporeal and non-corporeal unless otherwise regulated by special law. ${ }^{30}$ This definition is different compared to that of the current Kosovo law which does not give the definition but just states what is considered as a thing. ${ }^{31}$ The KDCC definition is different also from that of the most developed civil law countries (i.e., German and Austrian Civil Code).$^{32}$ The legal doctrine in comparative law is divided into two groups: a 'narrow' and 'broad' concept of things. For example, the German law $^{33}$ is considered as a jurisdiction that offers a narrow definition of things contrary to Austrian law ${ }^{34}$ which is

almost in all civil law jurisdictions.

28 For instance, the notaries do not have direct access to the land register for checking the real owners. Consequently, there are and can be cases of double contracts for the transfer of the same immovable property.

29 See below point 2 and 3.

30 KDCC, Article 39.

31 LPORR, Article 8 states: Assets are movable property, immovable property, and intangible rights.

32 For an overview under German and Austrian law see Gabriele Koziol and Helmut Koziol in cooperation with Andrew Bell and Samuel Fulli-Lemaire, Austrian Private Law - An Overview in Comparison with German Law and with References to English and French Law (Wien: Jan Sramek Verlag, 2017), 64-65.

33 BGB, Article 90: Only corporeal objects are things as defined by law.

34 ABGB, Article 285: Everything what is different form a person and that can be used by humans 
considered jurisdictions that offer a broad definition of things. ${ }^{35}$ The KDCC definition that things are considered corporeal and non-corporeal unless otherwise regulated by special law provides a general concept that does not exclude any possible item from the category of things. In particular, this is important in the modern time which is characterised with developed technology and transformation of economy.

Article 41 of the KDCC defines movable property as: Movables are independent corporeal things not permanently attached to the land or parts of land, and can generally be moved from one place to another, unless otherwise provided by law. This approach taken by the KDCC is similar with that of the $\mathrm{ABGB},{ }^{36}$ in contrast to the BGB which does not state the concept of movables. ${ }^{37}$

Additionally, Article 41 of the KDCC defines immovable property as: Immovables are a limited surface of land and the things permanently attached to the surface of land. Immovable is the land (agricultural, forests, pastures), construction areas, installations and constructions on and under it which are heavily attached to the ground, plants with their roots on the ground, and anything that cannot be moved from one place to another without being substantially damaged. It must be stated that the rules with regards to the concept of immovables do not differ from one legal system to another due to the principle that everything that is not movable is considered to be immovable property.

Finally, it remains to be clarified that that not all things can be transferred. Rather, in the practice and from the rules of other special laws and spirit of the legal system there are several restrictions for the transferable of both movable and immovable things. As a general rule, under the KDCC rule, only things that are in legal circulation may be subject to civil law relationships..$^{38}$ This rule is not enough satisfactory and there is space for a legal repair stating which things are transferable and which cannot be transferable through the contractual system.

\section{Acquisition of ownership of movable property based on a contract}

This form of acquisition of ownership by way of a legal transaction (hereafter: contract) is determined by Book 3, Article $865-872$. Generally, by these provisions, these conditions for the acquisition of ownership of movables must be met: $(i)$ existence of a valid contract; (ii) delivery of the property from the owner and the transferee.

is defined as an asset in a legal sense.

35 With regard to these solutions see Christian Von Bar and Ulrich Drobnig, The Interaction of Contract Law and Tort and Property Law in Europe - A Comparative Study (Munich: Sellier, European Law Publishers, 2004), 317-320.

36 ABGB, Article 293 defines movable property as the following: Assets which can be moved from one place to another without causing damage to their substance are movable. For more see Wolfang Faber, "National Report on the Transfer of Movables in Austria", in: National Report on the Transfer of Movables in Europe, eds. Wolfang Faber and Brigita Lurger, (Munich: Sellier, European Law Publishers, 2008), 55 et seq.

37 For more on this see Mary Rose McGuire, "National Report on the Transfer of Movables", in Germany in: National Reports on the Transfer of Movables in Europe, eds. Wolfgang Faber and Brigitta Lurger (Munich: Sellier, European Law Publishers, 2011), 69.

KDCC, Article 49. 
This requirement under KDCC Article 865 is referring to the delivery. Indeed, under this section several modes of delivery of the movable are recognised which have a direct impact on the acquisition of ownership. So far, under KDCC Article 865 (2), if the transferee is in possession of the movable asset, a valid legal transaction passing ownership is sufficient for the transfer of ownership. Further, under KDCC Article 865 (3), if the owner is in possession of the movable property, the delivery may be substituted for an agreement between the owner and the transferee by which the transferee obtains indirect possession of the movable property. Lastly, based on KDCC Article 865 (4), if a third party is in possession of the movable property, the delivery may be substituted for assignment, by the owner to the transferee, of the claim against the third party for the delivery of the movable property.

Under KDCC Article 866, the good faith acquisition (in Albanian: fitimi me mirëbesim) is recognised..$^{39}$ Thus, if the transferred movable asset does not belong to the transferor, the transferee nevertheless acquires ownership, unless he is not acting in good faith at the time of the delivery. From the good faith acquisition the lost and stolen property without the will of the owner is excluded ${ }^{40}$ and this rule protects the real owners of the movables.

Lastly, KDCC Article 872 determines that a movable is deemed abandoned if the owner unambiguously expresses his intention to irrevocably renounce his ownership over the property. Consequently, this is a form of loss of ownership over the movable property. This provision is similar with Article 959 of the BGB which determines that a movable becomes without owner if there is the intention of waiving ownership through giving up the possession of the thing.

\section{Acquisition of ownership in immovable property based on a contract}

The contractual transfer of immovable property follows a more formal process when compared with the transfer of movable property. Thus, under KDCC Article 873 these conditions have to be met in order to acquire ownership of immovables: (i) existence of a legal transaction (in this case a contract); (ii) the contract has to be valid; (iii) the contract has to be concluded in notarial form; (iv) the contract has to be registered in the register for the immovable property. Based on these requirements, the following issues have to be treated. Firstly, the validity of the contract has to be determined by the rules of Book 2 on Obligations. Thus, Book 3 on Property and Other

39 KDCC has followed the German Civil Code, Article 932 which says: As a result of a disposal carried out under section 929, the acquirer becomes the owner even if the thing does not belong to the alienor, unless the acquirer is not in good faith at the time when under these provisions he would acquire ownership. In the case of section 929 sentence 2, however, this applies only if the acquirer had obtained possession from the alienor. The acquirer is not in good faith if he is aware, or as a result of gross negligence he is not aware, that the thing does not belong to the alienor.

40 KDCC, Article 867. This article is in line with Article 935 of the German Civil Code which stipulates as the following: The acquisition of ownership under sections 932 to 934 does not occur if the thing was stolen from the owner, is missing or has been lost in any other way. The same applies, where the owner was only the indirect possessor, if the possessor had lost the thing. 
Real Rights does not provide rules regarding such validity. Secondly, the requirement that states that the contract has to be registered is of a constitutive effect as under German and Austrian law. ${ }^{41}$ The rules of registration are not subject to the KDCC but will continue to be regulated by the special law called Law on Establishment of an Immovable Property Right. ${ }^{42}$ Furthermore, during the transfer of immovables, an important role is given to the notaries as a result of the mandatory competence to perform notarial contracts for the transfer of immovables. ${ }^{43}$

As with other civil law systems and the current LPORR, the KDCC has also determined that ownership of immovables also extends to movable assets, which have become an integral part of the immovable property; further, if ownership of an immovable is acquired, it is presumed that the constituent parts are also acquired simultaneously ${ }^{44}$ The KDCC also contains rules for the relinquishment of the ownership of an immovable property, in the section of the acquisition of ownership. Such a relinquishment may occur in two forms: (i) the owner personally declares to the competent authorities (cadastral office) that he wishes to renounce from the immovable property and such a statement shall be registered in the immovable property rights register; (ii) the owner declares, with authorization, to the competent authorities (cadastral office) that he wishes to renounce from the immovable property and such a statement shall be registered in the immovable property rights register. ${ }^{45}$

In both cases, ownership over that immovable property will belong to the competent public body in the territory in which the immovable property is located. With the competent authority, the municipality must be understood. In such a case, the municipality also acquires the ownership with the registration of the title in the register which is kept by the cadastre. ${ }^{46}$

\section{CONTRACT AS A LEGAL TITLE}

Traditionally, under Kosovo law the definition of the contract was not given. Additionally, according to the rules on the formation of the contract, the meaning of the contract was constituted. This was not characteristic only for Kosovo law. By

41 For the similarities of Kosovo law and German law see Haxhi Gashi, "Acquisition and Loss of Ownership under the Law on Property and Other Real Rights (LPOORR): The influence of the BGB in Kosovo Law", Hans Law Review 9, № 1 (2013): 55.

42 Law on Establishment of an Immovable Property Right Register UNMIK Reg. 2002/22. This law has been amended twice: Law № 2003/13 on Amending and Supplementing Law N$^{\circ}$ 2002/5 on Establishment of the Immovable Property Rights Register; and Law No 04/L-009 on Amending and Supplementing Law No 2002/5 on Establishment of the Immovable Property Rights Register. For more on this law see generally Stefan Pürner and Abdulla Aliu, Legal Commentary of the Law on Establishment of an Immovable Property Right Register UNMIK Reg. 2002/22 (Pristina: UNMIK 2004).

43 Law No 06/L-010 on Notary published in Official Gazette № 23 of 26 December 2018.

44 KDCC, Article 873 (3).

45 KDCC, Article 875 (1). Similarly, is determined under German law. In this context, GBB in Article 928 (1) states: The ownership of a plot of land may be relinquished by the owner declaring the waiver to the Land Registry and the waiver being registered in the Land Register. 
contrast, even the most developed European Civil Codes provided such a solution (i.e., BGB and ABGB). Pursuant to Book 2 of the KDCC, a contract is defined as: An agreement between two or more parties which is intended to create, amend or terminate a binding legal relationship between them, or have any other legal effect. ${ }^{47}$ This definition of the contract under KDCC reflects the aim of the contract for what is concluded and is closely connected also with the transfer of property as the most often reason why is concluded the contract is the transfer of property. The Book on Obligations is divided into two sub-books: the (i) general part - main institutes; and (ii) special part - contracts. Generally, Book 2 is drafted based on the current Law of Obligations, as the rules are mostly dispositive and there are not many requirements by the actors of the Kosovo legal systems regarding the modernisation of these rules.

The main contracts which deal with the transfer of movable and immovable property are as follows:

- Contract for sale (in Albanian: kontrata për shitjen);

- Contract for donation (in Albanian: kontrata për dhuratën);

- Contract for barter (in Albanian: kontrata për këmbimin);

- Contract for lifelong maintenance (in Albanian: kontrata për mbajtjen e përjetshme);

- Contract for delivery (in Albanian: kontrata për dorëzimin).

Based on this list, two issues have to be clarified. Firstly, as a consequence of the freedom of contract principle,,$^{48}$ the parties are not limited to these contracts. Rather, the parties can conclude new types of contracts with which they can transfer the property pursuant to the freedom of contract principle (i.e., the contract for joint investment in immovable property is used very often in Kosovo).

As already presented, under Kosovo property law the validity (in Albanian: vlefshmëria) of the contract is one of the requirements for the contractual transfer of immovable property. ${ }^{49}$ The grounds for the validity and invalidity of the contract are provided by Book 2 on Obligations. ${ }^{50}$ In this context, it has to be mentioned that the current LOR does not provide a particular provision which determines the essential and non-essential elements. By contrast, these essential elements are the subject of special provisions under the LOR. ${ }^{51}$ According to KDCC Article 96, the essential

47 This definition is taken from Italian law. For this see and compare KDCC, Article 91 and Italian Civil Code, Article 1321. For further on the contract under Italian law see Alessio Greco, "National Report on the Transfer of Movables in Italy", in: National Reports on the Transfer of Movables in Europe, eds. Wolfang Faber and Brigitta Lurger (Munich: Sellier, European Law Publishers, 2008), 421.

48 KDCC Article 84 determines: Parties are free to regulate their contractual relations according to their will, subject to the limits established by mandatory provisions, public order and good custom. Within the limits referred, parties may conclude contracts other than those foreseen by law and determine their contents.

49 Traditionally this was required under Kosovo law. For this see also current LPORR, Article 36 (1) states: For the transfer of ownership on immovable property is required a valid legal transaction between transferor and transferee as a legal ground and the registration of the change of ownership in the immovable property rights register.

50 See also below point $\mathrm{V}$.

51 In comparative law is evident the determination of essential elements in one article. For this 
elements of a contract are as follows: (i) the consent of the will of the parties; (ii) the subject of the contract; (iii) the basis of the contract and (iv) the form, when required by this code or by a specific law. With this approach the KDCC has followed the Italian model..$^{52}$ Nevertheless, in the opinion of the authors, the current provision of the KDCC with regard to the essential elements is not sufficient as a consequence that lacks the capacity to contract. ${ }^{53}$ In particular, this is mandatory with regard to the contracts that transfer the immovables as a consequence of the participation of notary who is obliged by law to checks the capacity to contract of the parties. Thus, the working group of the Assembly of Kosovo competent for the review of the KDCC has to consider these additional rules. The existence of these essential elements is important because if there is not an agreement about these elements, the contract is not considered concluded..$^{54}$

\section{FURTHER INTERACTION OF LAW OF PROPERTY AND LAW OF CONTRACT UNDER KDCC IN CASES OF INVALIDITY OF TRANSFER}

In principle, the contract is concluded by the contractual parties to transfer the ownership. Nevertheless, the contract can be registered in the register, but after this such a contract may be declared invalid by the court. Consequently, the question arises of who will remain the owner of the thing (movable or immovable property). In such a case, the rules of the law of property will be applicable in combination with the rules of the law of contract. Thus, the KDCC Book 3 on Property and Other Real Rights answers the question of who will remain the owner. By contrast, Book 2 on Obligation regulates the grounds on the invalidity of the contract and the monetary restitution. ${ }^{55}$

Indeed, with regard to the proprietary effect of the contract, if it is declared invalid - the ownership remain to the party in favour of who is asked the invalidity. Further, the good faith acquisition is only recognised with regards to movable property. ${ }^{56}$ For immovable property, no special rule is determined on good faith acquisition of ownership with regard to the protection of third parties. ${ }^{57}$ This is different from

approach, see FCC, Article 1108 and ICC, Article 1325.

52 See ICC, Article 1325. For more on essential elements under Italian law see Alessio Greco, "National Report on the Transfer of Movables", in Italy in: National Reports on the Transfer of Movables in Europe, eds. Wolfang Faber and Brigitta Lurger (Munich: Sellier, European Law Publishers, 2008), 421-427.

53 FCC in Article 1108 (sentence number three) recognises the capacity to contract as an essential element of the contract. Under KDCC, the rules on capacity are determined by Book 1 on General Part (Article 16-20) and Book 2 on Obligations (Article 171-173).

54 KDCC Article 96 (1) states that: A contract is not concluded until the parties have reached an agreement on all essential elements of the contract.

55 The invalidity is divided in two categories: $(i)$ relative invalidity; and (ii) absolute invalidity. For this see KDCC (book 1) Article 58 and 59. Additionally, KDCC (book 2) Article 157-170.

56 With regard to good faith acquisition in movables see KDCC, Article 866. The same regulation is applicable under current LPORR, Article 22.

57 The good faith acquisition presented in this article has to be understood only with regard to the protection of third parties in cases of invalidity of contract. For other forms of acquisition of 
German law which has deeply established this principle.$^{58}$ In accordance with this, Austrian law also recognises this principle, but from a narrower point of view. ${ }^{59}$ This legal solution provided by Austrian and in particular by German would be very useful for Kosovo legal system and further it would go deeper with regard to the protection of third parties. Consequently, such a rule has to be considered to be incorporated during the finalisation of the KDCC by the Assembly of Kosovo.

Lastly, the process can be followed by the application which has as its base the law of obligations as well as the rules of unjustified enrichment ${ }^{60}$ and tort law. ${ }^{61}$ The application of these rules (i.e. the depth of their application) is subject to a court decision pursuant to contested civil procedure and the request of the contractual parties through the claim. ${ }^{62}$

\section{CONCLUSIONS}

The legal influence of Kosovo contract law in transfer of property is a topic that is not treated directly by the local doctrine. By contrast, these two branches are treated as separate and with different functions. Despite this doctrinal approach, from a law perspective the law of contract and law of property have to be seen as common legal tools which fulfil the role of each other's fields in the process of the transfer of property. The KDCC rules of property for the transfer of movables and immovables along with many other conditions (i.e., delivery of movables, registration of immovables) also require that the contract is valid. Thus, the contract serves as a

ownership remain applicable the requirement of existence of the good faith. For instance, the good faith is needed to be present in the acquisition by prescription under KDCC Article 877.

58 Article 892 BGB states that: In favour of the person who acquires a right in a plot of land or a right in such a right by legal transaction, the contents of the Land Register are presumed to be correct, unless an objection to the accuracy is registered or the inaccuracy is known to the acquirer. Where the person entitled is restricted in favour of a particular person in his disposition of a right entered in the Land Register, the restriction is effective in relation to the acquirer only if it is apparent from the Land Register or known to the acquirer. Where registration is necessary for the acquisition of the right, the knowledge of the acquirer at the date when the application for registration is made or, if the agreement required under section 873 is reached only later, the date of agreement is conclusive. For further see Lukas Rademacher, "German Law", in: Invalidity of Contract and the Protection of Third Parties' Acquisitions of Land, eds. Marco Rizzuti, Erhan Kansisli and Lukas Rademacher, Italian Law Review 05, № 01 (2019): 192-193.

59 Gabriele Koziol and Helmut Koziol in cooperation with Andrew Bell and Samuel Fulli-Lemaire, Austrian Private Law - An Overview in Comparison with German Law and with References to English and French Law (Wien: Jan Sramek Verlag, 2017), 73.

60 KDCC, Article 268 states: Any person that unjustly becomes enriched to the detriment of another shall return whatever he has received or shall otherwise indemnify the other for his loss.

61 KDCC, Article 206 states: "The damage is to diminish one's wealth as ordinary damage and to prevent its growth as loss of profit, as well as causing the other's physical pain, psychic suffering or fear as moral damage".

62 The contested procedure is regulated by Law No 03/L-006 on Contested Procedure published in Official Gazette No 38 of 20 September 2008. 
legal title (iustus titulus) and follows the causal transfer system, similar to Austrian law, but contrary to the German abstract system and the French consensual system. This legal model provided by KDCC is a continuity of the current civil law framework. The causal system of transfer of property is a proper system for the legal tradition of Kosovo and serves as a guarantee for the contractual parties with regard to the legal certainty. In particular, it is crucial the determination by the KDCC that the registration of contract has a constitutive effect and by this approach is followed the German and Austrian model contrary to French system that is based in the declarative effect of the registration of contract.

For the first time in history of legislation of Kosovo through the KDCC is given the definition of the contract. The contract is defined as: An agreement between two or more parties which is intended to create, amend or terminate a binding legal relationship between them, or have any other legal effect. This concept of contract determined by KDCC has followed the Italian law and it fits to the legal effects for what is concluded the contract and in particular it shows the aim of the transfer of property. Furthermore, KDCC required a valid contract for transfer of movables and immovables. Validity of the contract is determined by rules of KDCC Book 1 on General Part and Book 2 on Obligations which generally have introduced a unitary approach for the contract of the ownership both for movables and immovables. As the current law, this will create divergences in the practice as a consequence that in particular the transfer of immovables requires more formalities than the transfer of movables. The invalidity of the contract can be absolute or relative. As in other jurisdictions, the absolute nullity is a heavy type of invalidity and is considered to be against public interest, contrary to relative nullity that attacks the private interest of the contractual parties. This makes unable the regular transfer of property. Another influence of contract law in transfer of property is expressed regarding the restitution. This is expressed as a consequence of the application of tort law and unjustified enrichment which are tools to establish the equal considerations of the contractual parties in cases of the nullity of contracts.

Another issue that is needed to be addressed in the finalization of the KDCK is to determine whether registration of ownership based on a valid contract can or cannot be disputed in civil procedure after the use of the internal administrative procedures within the cadastre. Furthermore, there should be clarified whether the dispute for registration is allowed in order to clarify the nature of the data in the register (i.e, whether they are of an absolute or relative nature).

\section{BIBLIOGRAPHY}

\section{Books and articles}

1. Akkermans, Bram. "Property Law and the Internal Market". In: The Future of European Property Law, eds. Sjef van Erp, Arthur Salomons and Bram Akkermans, 199-250. Munich: Sellier, European Law Publishers, 2012.

2. Akkermans, Bram. The Principle of Numerus Clausus in European Property Law. Antwerp - Oxford - Portland: Intersentia, 2008. 
3. Faber, Wolfang. "National Report on the Transfer of Movables in Austria". In: National Report on the Transfer of Movables in Europe, eds. Wolfang Faber and Brigita Lurger, 1-218. Munich: Sellier, European Law Publishers, 2008.

4. Füller, Jens Thomas. "The German Property Law and its Principles". In: Rules for the Transfer of Movables - A Candidate for European Harmonisation or National Reforms?, eds. Wolfgang Faber and Brigitta Lurger, 197-215. Munich: Sellier, European Law Publishers, 2008.

5. Gashi, Haxhi. "Pjesa e Përgjithshme e të Drejtës Civile - Parimet e Përgjithshme". In: Hyrje në Sistemin Ligjor në Kosovë, eds. Arsim Bajrami, Enver Hasani, Hajredin Kuçi, Iliriana Islami, Haxhi Gashi, Iset Morina, Avni Puka, Azem Hajdari, Mirlinda Batalli and Remziije Istrefi, 168-219. Prishtinë: Akademia e Drejtësisë së Kosovës, 2019.

6. Gashi, Haxhi. "Acquisition and Loss of Ownership under the Law on Property and Other Real Rights (LPOORR): The influence of the BGB in Kosovo Law". Hans Law Review 9, No 1 (2013):41-60

7. Greco, Alessio. "National Report on the Transfer of Movables in Italy". In: National Reports on the Transfer of Movables in Europe, eds. Wolfang Faber and Brigitta Lurger, 341-506. Munich: Sellier, European Law Publishers, 2008.

8. Koziol, Gabriele and Helmut Koziol in cooperation with Andrew Bell and Samuel FulliLemaire. Austrian Private Law - An Overview in Comparison with German Law and with References to English and French Law. Wien: Jan Sramek Verlag, 2017.

9. McGuire, Mary-Rose. "National Report on the Transfer of Movables in Germany". In National Reports on the Transfer of Movables in Europe, eds. Wolfgang Faber and Brigitta Lurger, 1-192. Munich: Sellier, European Law Publishers, 2011).

10. Pürner, Stefan and Aliu, Abdulla. Legal Commentary of the Law on Establishment of an Immovable Property Right Register UNMIK Reg. 2002/22. Pristina: 2004.

11. Rademacher, Lukas. "German Law". In: Invalidity of Contract and the Protection of Third Parties' Acquisitions of Land, eds. Marco Rizzuti, Erhan Kansisli and Lukas Rademacher. Italian Law Review 05, № 1 (2019): 173-195.

12. Rataine, Eleanor Cashin. "National Report on the Transfer of Movables in France". In: National Reports on the Transfer of Movables in Europe, eds. Wolfang Faber and Brigitta Lurger, 1-188, National Reports on the Transfer of Movables in Europe. Munchen: Sellier, European Law Publishers, 2011.

13. Van Vliet, Lars. Transfer of Movables in German, French, English and Dutch law. Nijmegen: Ars Aequi Libri, 2000.

14. Von Bar, Christian and Ulrich Drobnig. The Interaction of Contract Law and Tort and Property Law in Europe - A Comparative Study. Munich: Sellier, European Law Publishers, 2004.

15. Zimmermann, Reinhard. "The Civil Law in European Codes". In: Regional Private Laws and Codification in Europe, eds. Hector L. MacQueen, Antoni Vaquer, Santiago Espiau Espia, 18-59. New York: Cambridge University Press, 2003.

16. Zweigert, Konrad and Hein Kötz, translated from the German by Tony Weir. Introduction to Comparative Law. New York: Oxford University Press, Second Edition, 1987.

Legal acts

1. Austrian Civil Code (AGBG), translated in English by Peter Andreas and Erika Pircher. Wien: Lexis Nexis, 2013.

2. French Civil Code. Available in English at: file://C:/Users/bashk/AppData/Local/ Packages/M icrosoft.MicrosoftEdge_8wekyb3d8bbwe/TempState/Downloads/ Code_22\%20(1).pdf Last seen on 26.4.2019.

3. Italian Civil Code, translated in Albanian by Lisenko Moçka. Tirana: Shtëpia Botuese "Dudaj" and "Barleti Press", 2014. 
4. Law $\mathrm{N}^{\circ} 03 / \mathrm{L}-006$ on Contested Procedure published in Official Gazette $\mathrm{N}^{\circ} 38$ of 20 September 2018.

5. Law $\mathrm{N}^{\circ} 03 / \mathrm{L}-154$ on Property and Other Real Rights published in Official Gazette $\mathrm{N}^{\circ} 57$ of 4 August 2009.

6. Law $\mathrm{N}^{\circ} 04 / \mathrm{L}-077$ on Obligational Relationships published in Official Gazette $\mathrm{N}^{\circ} 16$ of 19 June 2012.

7. Law $\mathrm{N}^{\circ} 06 / \mathrm{L}-010$ on Notary published in Official Gazette $\mathrm{N}^{\circ} 23$ of 26 December 2018.

8. Law No $2002 / 5$ on Establishment of the Immovable Property Rights Register published in official Gazette $\mathrm{N}^{\circ} 34$ of 1 August 2008.

9. Law No 2003/13 on Amending and Supplementing Law No 2002/5 on Establishment of the Immovable Property Rights Register published on Official Gazette, Year III/No 34 of 01 August 2008.

10. Law $\mathrm{N}^{\circ} 2004 / 26$ on Inheritance published in Official Gazette $\mathrm{N}^{\circ} 43 / 74$.

11. Law No 2004/32 on Family published Official Gazette, Year I, № 4 of September 2006.

12. Law on Obligational Relationships published in Official Gazette of forms Yugoslavia $\mathrm{N}^{\circ}$ 29/78 and amendments of 1985 and 1989 published in Official Gazette № 39/85 and 5/89.

13. Slovenian Obligation Code published in Official Gazette of the Republic of Slovenia, $\mathrm{N}^{\circ}$ $83 / 2001$.

14. The second $\mathrm{KDCC}$ in Albanian language is available at: https://md.rks-gov.net/page. aspx? id=1,94. Last seen on 26.2.2019. 


\author{
Haxhi Gashi* \\ Bashkim Preteni**
}

Sažetak

\title{
PRIJENOS VLASNIŠTVA TEMELJEN NA PRAVILIMA VLASNIČKOG I UGOVORNOG PRAVA U PREDSTOJEĆEM NACRTU GRAĐANSKOG ZAKONIKA KOSOVA
}

U većini građanskopravnih sustava ugovor je najčešće korišteni pravni naslov za prijenos vlasništva (pokretne i nepokretne imovine). Vrlo često se imovinsko pravo i ugovorno pravo smatraju različitim i njihova uloga može razmatrati iz različitih pravnih perspektiva. To je usko povezano s vrstom sustava prijenosa vlasništva temeljem toga primjenjuje li se (austrijski) kauzalni, (njemački) apstraktni ili (francuski) konsenzualni sustav. Kosovo je u procesu građanskopravnog kodificiranja i kosovski Nacrt građanskog zakonika slijedio je primjenu kauzalnog sustava prijenosa imovine, a međuodnos dvije spomenute grane građanskog prava je nužan i samo zajednički pregled može objasniti ugovorni prijenos imovine. Cilj ovog rada je usredotočiti se isključivo na utjecaj pravila ugovornog prava u vezi sa stjecanjem vlasništva nad pokretnom i nepokretnom imovinom utvrđenom Nacrtom građanskog zakonika Kosova.

Ključne riječi: kosovsko pravo; Građanski zakonik; Zakon o vlasništvu; Zakon o ugovorima; vlasništvo; ugovor.

* Dr. sc. Haxhi Gashi, izvanredni profesor, Pravni fakultet Sveučilišta „Hasan Prishtina“ u Prištini; haxhi.gashi@uni-pr.edu. ORCID: https://orcid.org/0000-0002-2752-5646.

** Dr. sc. Bashkim Preteni, predavač, Pravni fakultet Sveučilišta „Hasan Prishtina“ u Prištini; bashkim.preteni@uni-pr.edu. ORCID: https://orcid.org/0000-0002-2297-5584. 